\title{
The hemşehrilik and the village: the stakes of an association of former villagers in Ankara
}

\section{Benoit Fliche}

\section{(2) OpenEdition \\ Journals}

\section{Electronic version}

URL: http://journals.openedition.org/ejts/385

DOI: $10.4000 /$ ejts.385

ISSN: $1773-0546$

\section{Publisher}

EJTS

\section{Electronic reference}

Benoit Fliche, "The hemşehrilik and the village: the stakes of an association of former villagers in Ankara », European Journal of Turkish Studies [Online], 2 | 2005, Online since 04 March 2015, connection on 16 February 2020. URL : http://journals.openedition.org/ejts/385; DOI : 10.4000/ejts. 385 


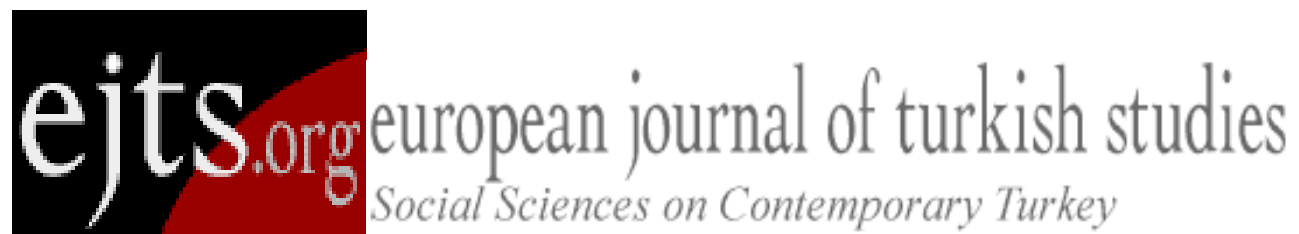

Citation : Fliche, Benoit (2005) 'The hemşehrilik and the village: the stakes of an association of former villagers in Ankara', European Journal of Turkish Studies, Thematic Issue $\mathrm{N}^{\circ} 2$, Hometown Organisations in Turkey, URL: http://www.ejts.org/document385.html To quote a passage, use paragraph (§).

\title{
The hemşehrilik and the village: the stakes of an association of former villagers in Ankara
}

\author{
Benoit Fliche
}

\begin{abstract}
This article analyses the reasons behind the successes and failures of collective actions initiated by an association of former villagers. Members of this association did not adhere to all these collective actions, as these must be acceptable in semiotic terms, and must also conform to the hemşehrilik egalitarian ideal. One of the main obstacles to associative mobilisation is that the village itself is a conflictual and competitive place. This contrast between village and association shows that this is more an association of hemşehri than a village association. This difference invites us to reconsider the relationship which former villagers can (or cannot) have with their village, and to question the signification of the term hemşehri.
\end{abstract}


Citation : Fliche, Benoit (2005) 'The hemşehrilik and the village: the stakes of an association of former villagers in Ankara', European Journal of Turkish Studies, Thematic Issue $\mathrm{N}^{\circ} 2$, Hometown Organisations in Turkey, URL: http://www.ejts.org/document385.html

To quote a passage, use paragraph (§).

This article aims to understand the symbolic and social reasons behind the success and failure of collective actions arising within a hemşehri association, originating in an Alevi village in central Anatolia (district of Sorgun)1. Two conditions for success will be deciphered. First, these collective actions have to be compatible with the hemşehrilik ideal. The term 'ideal' refers to an ensemble of values to which a group tries to conform. The hemşehrilik ideal is not easily apparent and only appears after analysing the reasons why collective associative actions cannot be directed towards the village. In fact, the village is a place of conflict, which makes it difficult for any associative mobilisation of its former villagers. The association is forced to turn its back on the village - its original reason for existence as is evident by its name (Kayalar Köyü Yaşatma ve Yardımlaşma Derneği, Association for mutual aid/assistance and revitalization of the village of Kayalar). In this way we will show that it is more an association of hemşehri than a 'village' association. This difference will allow us to de-essentialize the tie that former villagers can (or cannot) have to their village of origin and, as a result, to question the underlying meaning of the term hemşehri.

[2] One of the main limitations to associative mobilisation is the village itself. But does this mean that mobilisation taking place outside the village has better chance of success? This condition alone is not sufficient, as associations also have to conform to certain semiotic conditions. To illustrate this, we will focus on acts concerned with heritage - 'patrimonialisation' - the invention or revival of tradition (Hobsbawm and Ranger 1983; Lenclud, 1987). The importance of this second element will be demonstrated using two instances where collective actions have failed: the semah (a ritual dance), and the cem (an Alevi religious ceremony). Lastly we will take the example of the aşure çorbası - a religious commemoration during which a sweet soup is eaten, which will allow us to demonstrate that these two conditions have to be combined for a collective action to be a success.

\section{Back to the village?}

[3] The association of Kayalar is characterised by its lack of obviousness: 'An association? For what?' was the reaction of many Kayalarl ${ }^{2}$ when a number of them were asked to participate in the creation of an association. For an observer of the Turkish associative phenomena this reaction

${ }^{1}$ This text has been translated by Sarah Cannici, Nick Davies and Chandni Maroke.

2 'Originating from Kayalar'. 
Citation : Fliche, Benoit (2005) 'The hemşehrilik and the village: the stakes of an association of former villagers in Ankara', European Journal of Turkish Studies, Thematic Issue $\mathrm{N}^{\circ} 2$, Hometown Organisations in Turkey, URL: http://www.ejts.org/document385.html

To quote a passage, use paragraph (§).

can come as a surprise; the number of village associations in Turkey is so high that they must surely serve a purpose. However, in the case of the village of Kayalar, the relevance of creating an association was questioned by everybody.

[4] The first reason was the fear the Kayalarlı have of the State. They show a certain faintheartedness for anything remotely concerned with the public taking of responsibility. This is explained by the still very vivid memory of the 'political period' (siyaset dönemi, 1975-1980), of the coup d'Etat of $12^{\text {th }}$ September 1980 and severe depolitisation - and the ensuing repression that followed. 'Association' to them meant 'örgüt'; 'political organisation' - a term with a negative connotation alluding to the armed left-wing organisations of the 1970s. Many fell prey to a fear that their participation in an association would bring them political and legal harm.

[5] The second reason stems from the history of migration and the highly competitive social structure of this little village. It was among the few in the region to have completely disappeared after the mass emigration of the 1970s. Its inhabitants abandoned the village to settle in Sorgun, Ankara or Europe (France and Germany). In the Turkish capital - the most popular destination for migrants the Kayalarlı all gathered in a district above the Yenimahalle, but in spite of this, they did not create an 'urban village'. With urbanisation, the village community crumbled as a result of a social ventilation arising from the different migratory influxes, and the initial competitive and 'agonistic' social structure. As much as the community was no longer a social space for political mobilisation, or a matrimonial one, it was even less a space for sociability (Fliche 2004). Taking this into consideration, what use does an association of villagers have when the village - as a physical space, a community and a social space have disappeared?

[6] The third reason behind the general reluctance is the fear that this association would reignite conflicts between families, which had been buried following migration. During the three decades prior to the exodus, the history of this village was characterised by serious animosities, but which never gave rise to a kan davası ('blood trial', vendetta). There was severe competition between the lineages, aggravated by the lack of land and pasture. Restoring links between families might result in the resurgence of conflicts existing prior to the rural exodus.

[7] These were the three main hurdles, which those behind the mobilisation succeeded in overcoming. The creation of the association in 1997 corresponds chronologically with the associative 
Citation : Fliche, Benoit (2005) 'The hemşehrilik and the village: the stakes of an association of former villagers in Ankara', European Journal of Turkish Studies, Thematic Issue $\mathrm{N}^{\circ} 2$, Hometown Organisations in Turkey, URL: http://www.ejts.org/document385.html

To quote a passage, use paragraph (§).

craze in Turkey for the hemşehrilik (Bayraktar 2001; Massicard 2001, Pérouse 2005). It also illustrates the social construction represented by an hemşehri association, as it is not born from a 'spontaneous' movement. It is, on the other hand, the result of a collective mobilisation led by a small number of individuals originating from the village. There is not so much a collective enthusiasm amongst the 'social entrepreneurs' who, profiting from the wave, detach themselves from the movement and become its leaders. In fact, the opposite is closer to the truth: the individuals detach themselves from the group and decide to mobilise it (Siméant 1998: 53).

[8] The association of Kayalar was principally founded by a former migrant from France who returned to Turkey after a decline in his fortunes. He had the idea of bringing a totally deserted village back to life and settling there. His return can be seen as a kind of revenge on life, or as the recovery of a social prestige lost during his period of misfortune. But the reasons he exposes are mainly aesthetic, for instance, that 'the rural life' appears to him to be far more pleasant than the urban one. Despite his thirty years of absence, this former gurbetçi (migrant) quickly succeeds in constructing a social network. When in December 1996 he returns to Ankara and makes the decision to found an association, he has almost no contact with the former inhabitants of Kayalar. Back then, his social network is limited to his familiars. He is unknown in the district and has no useful connections. He speaks to his cousin about the project, who puts him in contact with someone who had tried to create an association a few years earlier - but without success due to administrative difficulties. A small but very determined group of people surround him. It is made up of approximately a dozen of men aged between thirty and fifty years old who spent their childhood in the village. Despite living in Ankara, they have often experienced migration to Europe and all joined an Alevist ${ }^{3}$ or folkloric association for a short period of time.

[9] For the new association, they had to reform links broken by migration and the process of social differentiation. After three months of door-to-door canvassing, they succeeded in recreating a network of former villagers. These former villagers were tentatively convinced with arguments drawing on feelings of a sense of common belonging, as well as those which took advantage of the

${ }^{3}$ Alevi and 'Alevist' have to be distinguished: the first term refers to membership of a religious denomination, while the second terms refers to Alevism, an ideology promoting alevity as a reason for political action (Massicard 2002 : 24). 
Citation : Fliche, Benoit (2005) 'The hemşehrilik and the village: the stakes of an association of former villagers in Ankara', European Journal of Turkish Studies, Thematic Issue $\mathrm{N}^{\circ} 2$, Hometown Organisations in Turkey, URL: http://www.ejts.org/document385.html

To quote a passage, use paragraph (§).

competitive tendencies between villages. For example: 'Abalı (the neighbour village) has an association and we don't'; 'We are from this village, it is a shame that this will be forgotten'.

\section{Picnics, the generation gap and the reactivation of psychological attitudes}

[10] In 1998, to mark the consolidation of the rebirth of this network of former villagers, a picnic was organised by the key actors near the city of Ankara, thereby reviving a classic associative activity. Its clear success shows that the mobilisation was about to succeed. The picnic became an annual event and the association soon decided that it had to take place in the village. In this way the hemşehri would meet in the village each year. This association picnic was held in Kayalar until that of August 2001, which ended with several brawls between the different families: 'they arrived and instead of meeting, dancing and visiting the village together, they stayed in their own little corners. They did not talk with each other and started to go around the village to make sure that nobody was encroaching upon their land. They went to the fields to do this. In the end, with the alcohol, there were some fights' recalls one of the organisers.

[11] This conflictual situation can first be explained by the new position which the village occupies in this network of former villagers. At the same time as the creation of this association, a parallel movement of migration back to the village was initiated. Several families rebuilt houses there and made the place a summer holiday retreat. Yet with this return, not only is the village converted into a holiday village, it also once more becomes a source of conflict between families, who now share in a common stake. They begin once again to see themselves in relation to the others; they recreate a social setup with conflicts and calumniations. Why does this return to the village generate a conflictual environment? To find the answer we have to look into the twenty or so legal cases opened in the village.

[12] In 2002, a total of twenty legal hearings were ongoing regarding about fifteen houses, which are unoccupied six months of the year; an astonishing number according to the sub-prefect $(\text { kaymakam })^{4}$. Of course, these hearings stoke the animosities between families, but above all, they

${ }^{4}$ Often these lawsuits are a means of perpetuating a fraud. A Registered Land Plan of the village was made at the beginning of the 1950s, and normally every transaction regarding land has to take place with a tapu, the registered deeds to the property. When these do not exist, as in the case of a village which has not had a 
Citation : Fliche, Benoit (2005) 'The hemşehrilik and the village: the stakes of an association of former villagers in Ankara', European Journal of Turkish Studies, Thematic Issue $\mathrm{N}^{\circ} 2$, Hometown Organisations in Turkey, URL: http://www.ejts.org/document385.html

To quote a passage, use paragraph (§).

reveal the two ways of thinking by the main protagonists of these claims, which are the roots of this transformation into a conflicting environment.

[13] The actions are mainly brought by büyükler (the 'elders'). The influence for this generation is clear: all the 'belligerents' are over sixty-five, and had experienced a longer period of socialisation in the village, leaving it as adults. They have been the less receptive to the mobilisation initiated by the younger persons (under fifty), whose socialisation mainly took place outside the village. But these büyükler are dominant in the new social configuration. They have at their disposal an authority legitimised by the traditional hierarchy arranged according to gender and age (Gokalp $1980)^{5}$. Their frame towards the village is vastly different to that of the younger generation. Two principle attitudes can be seen: one that can be qualified as 'competitive', and the other, linked with the first, as 'egalitarian'.

[14] Their way of relating to their place of origin is determined by a pre-existing 'competitive' framework, in which the neighbour is first and foremost seen as a competitor, and even an enemy. This attitude is a product of village life in the 1960s, which was characterised by a shortage of food and land.

[15] Taking, as a paradigm example, an affair which took place in the middle of the 1980s. At the beginning of that decade, only two people remained in the village. Both had bought a particular breed of cow promoted by the Turkish government. Following an epidemic half of the livestock died. The government being at fault, the two farmers were to receive compensation from a civil servant coming from outside the village. As there was no one else living there, the two farmers were to bear testimony for each other and declare how much his neighbour's dead cows were worth. One would

Registered Land Plan drawn up, the individuals wishing to sell their land sign a recognition of sale (senet) and give it to the new buyers. The senet is valid only if there is no tapu; if there is one, the senet has no legal validity. The fraud consists of selling a piece of land with a senet, under the pretence that the tapu has been lost, and to then initiate a legal claim in which the tapu is produced. The results are quite remarkable: in general, the claimant wins his case, recovers the land he had sold a few years earlier and receives an indemnity. The loser pays the costs of the trial. Sometimes a claimant will raise a claim of adverse possession and exploitation of a piece of land, but there is no legal act of sale, thus there are many possibilities of starting this kind of legal proceeding. In fact, the farmers of the neighbouring villages destroyed the stone piles (sınır, frontier), which, as their name suggests, mark the boundaries of property, in order to illegally exploit the fields of absent Kayalarlı. The action can also be brought for communal land, for example the illegal use of the public highway or common grazing land.

${ }^{5}$ This hierarchy has not always been the same, as demonstrated by Hamit Bozarslan (1999) for the 1970s. 
Citation : Fliche, Benoit (2005) 'The hemşehrilik and the village: the stakes of an association of former villagers in Ankara', European Journal of Turkish Studies, Thematic Issue $\mathrm{N}^{\circ} 2$, Hometown Organisations in Turkey, URL: http://www.ejts.org/document385.html

To quote a passage, use paragraph (§).

think that they would have reached an understanding to increase the price for both of them, but the exact opposite happened: one of the neighbours declared a price which was half the value of the dead cows, which led the other to do the same, and so both lost money instead of gaining. The lack of trust between the two farmers and their competitive mindset could not be clearer 6 .

[16] The second frame is more of 'egalitarian' in nature, and finds its expression in an obsessive preoccupation with communal property and its possible selfish privatisation. Public property must stay common and everybody must have equal access to it. This approach is the result of the collectivisation of 'free', i.e. inalienated public goods (Cuisenier 1975: 205). An example will illustrate this.

[17] One day, the uncle of one of the Kayalarlı who had returned to Kayalar arrives in the village with a copy of the Registered Land Plan and shouts to his nephew: 'It appears that you have encroached upon the main road with your fence and that you closed a track with your trough!' Taken aback, the nephew asks who had said that. 'In Ankara, people say that!' The argument lasts an hour, the new villager trying to explain to his uncle that if the track is now closed, it is because it now serves no purpose and it would be better for tractors to use another route; that his fence does not in any way encroach upon the main road. Every explanation is useless... 'In Ankara, people say that you cut off roads!' the angry uncle repeated. 'Because you understand,' interjects a neighbour of the same generation as the nephew, 'the old people and others, they want everything to stay as it was before. And before - you know - they never did anything to a track. Even if it was useless, they never changed anything. For them it is the same. They don't want people to change the tracks at all, even if they have become useless. Before, they were afraid of jealousy, of the dedikodu'. It is to be borne in mind that the non-appropriated communal goods are not limited solely to village space: the association is also considered to be part of it.

\section{The impossible associative mobilisation towards the village}

[18] The consequences of the revival of these frames led to the demobilisation of a part of its members. One of the differences with village life in the 1970s is that nothing forces the Kayalarlı to

${ }^{6}$ As we will see later on, at that time, no figure of authority was present who that could have presided over the matter. 
Citation : Fliche, Benoit (2005) 'The hemşehrilik and the village: the stakes of an association of former villagers in Ankara', European Journal of Turkish Studies, Thematic Issue $\mathrm{N}^{\circ} 2$, Hometown Organisations in Turkey, URL: http://www.ejts.org/document385.html

To quote a passage, use paragraph (§).

adopt a conflictual standpoint, as they can very easily avoid every kind of confrontation. In fact, with the appearance of conflicts, many of them decided to distance themselves from the 'cause' of this competitive polarisation by refusing to return to the village for any reason. They prefer to live in a sociability 'inspired' by the village - in a way of feeling a common sense of belonging; and participating in associative activities which does not place them in direct rivalry and does not bring back to life any competitions between families. Between the sociability network of former villagers and the village (Kayalar), they chose the first. The result is a situation in which the network of former villagers shuns the village of origin as its 'link', despite this being the very reason for its existence. To the members of the association, the village appears as a danger. In July 2002, the leaders of the village association decide not to organise the pick-nick in the village but in a national park near Ankara. The village as a place is an obstacle for the 'village' as a sociability network: the village is against the 'village'.

[19] The resurrection of the 'egalitarian' mindset has consequences for the mobilisation of associative entrepreneurs themselves: the renewal of the association's officers always presents a serious problem as there are very few members who are ready to become its leaders. In addition to a reluctance for taking any kind of civic responsibility, members fear defamation (dedikodu): 'they are afraid that people will accuse them of subverting funds or taking advantage of the association. But there is no money,' one of the founders said. 'People' mainly mean the büyükler who keep the 'windmills of calumniation' going (Elias 1986). The accusation of subverting funds of an association or about its use for private means, is in fact against using it as a personal resource (prestige, electoral importance), which could possibly be beneficial in other contexts. We find here the 'egalitarian' mindset, which in actual fact, is a denunciation of the appropriation of communal goods.

[20] As a result, the initiators of the movement can no longer use the means of the association to mobilise the group for the village. All associative action towards the village is forbidden, while paradoxically its main function should be to contribute to the 'revitalization' (yaşatma) of the village. The first explanation is the straining of inter-familial relations, with the reappearance of the village as a common stake. The second is that all individual initiative within the association is perceived as a potential attempt to despoil the village's and the association's communal goods for private gain. Thus, steps to regenerate the village such as the restoration of the cemetery and the 
Citation : Fliche, Benoit (2005) 'The hemşehrilik and the village: the stakes of an association of former villagers in Ankara', European Journal of Turkish Studies, Thematic Issue $\mathrm{N}^{\circ} 2$, Hometown Organisations in Turkey, URL: http://www.ejts.org/document385.html

To quote a passage, use paragraph (§).

construction of fountains, are not carried out by the association, but are acts of evergetism, sometimes collective, as was the case with the plantation of a forest. Some social entrepreneurs have succeeded in mobilising all young men living in Ankara, originating from the village, to help them plant a few thousand young trees in the pouring rain and muddy conditions. Even if the people initiating this mobilisation were in positions of responsibility in the association, and even if this mobilisation affected the majority of families from Kayalar, and that these young men were members of the association, this mobilisation was entirely separate from the association. The new forest was planted neither with money from the association nor in its name.

[21] A last example will be given of the construction of the tekke (holy site). The founder of the association and one of the leading members had taken the decision to construct a little building, which would serve as a tekke, at the base of the sacred village rocks. 'To allow everyone to carry out their sacrifices in peace, so that they could have water and a fireplace with which to cook the lamb. We want to install electricity so that we may spend evenings there', one of the two men behind the project told us. This project, which was to benefit all of the Kayalarlı required financing. About ten people were personally contacted by the two men for help in supplying the sand, stones and the roof. For both of them it was out of the question to use the association to raise the money. This would have caused a stir, as the second constructor explains, 'in Ankara, they say that if I'm looking to improve the village, it is to be able to sell it afterwards. This is the reason why.... we don't ask the association for help. We ask those who are interested in participating'. The reason behind the impossibility of investment in the village by the association appears clear: it all stems from the notion of using the association as a social springboard for personal ambition. On the other hand, evergetism does not result in bad-mouthing, as this is independent from the communal property.

\section{Villagers or hemşehri ?}

[22] The importance of the egalitarian framework in the refusal of the associations' members to place themselves in a competitive situation leads us to the conclusion that the Kayalarlı now see themselves more as a group of hemşehri, than a group of villagers. What is the difference between the two concepts? Literally, hemşehri means 'those who come from the same town', but a more pragmatic analysis allows us to discover a multitude of interpretations (Güneş Ayata 1990 : 97 ; Erder 
Citation : Fliche, Benoit (2005) 'The hemşehrilik and the village: the stakes of an association of former villagers in Ankara', European Journal of Turkish Studies, Thematic Issue $\mathrm{N}^{\circ} 2$, Hometown Organisations in Turkey, URL: http://www.ejts.org/document385.html

To quote a passage, use paragraph (§).

1996 : 109). Turkish people have a very broad conception of the term: two people originating from the same district and meeting in another will call each other hemşehri, exactly as would two Turkish migrants originating from different regions but meeting abroad. The sense of common belonging expressed by the word is therefore not precise: it can refer to the village, district or country, according to the context in which the people meet. This spatial polysemy does not have to hide a more precise label when compared with the use made of this term in rural society in the 1960s. According to my sources, in the village, the term was used to address a stranger. Not just any kind of stranger: villagers would never have used the term while speaking to a civil servant, that is to say somebody of a superior social standing. The social function is not to denote a common geographical origin, but to construct a link so that the speaker is not anonymous any more, and therefore make it possible to relate to him so as to have a chat or offer a çay? ${ }^{7}$. As much as it is pre-supposes a common geographical belonging, şehir - the city; the emphasis has to be put on the prefix hem - meaning similarity, 'the same'. Hemşehri is a more than just a geographical link, it denotes a relationship of equality, and is therefore not intrinsically linked to the feeling of a common geographical belonging. In fact, my sources do not use this term to refer to the village community; they prefer the term 'millet ('the people') or more simply 'köy' - the village. The difference between a group of hemşehri and the 'village' would ultimately be that with 'village', we are in a social space differentiated by relationships characterised by unequal relationships, whereas a group of hemşehri is characterised by a group of equals 8 . In this way the hemşehrilik ideal appears, meaning a collection of norms to which a group attempts to conform, manifested here by the importance of equality between members and in regard to communal property. Hereafter, for a collective action to be successful amongst members of the association, it must necessarily fit the ideal of the hemşehrilik. That said, if this characteristic is necessary, it is far from sufficient.

7 Tea, çay, is a beverage drunk throughout the day and offered freely to visitors.

${ }^{8}$ At this point we have to make clear that unlike the study conducted by Shankland (2003), no families had a superior lineage to others by reason of a particular religious charisma. No family was 'holy' or sacred, but this does not necessarily imply that all relationships were based on an equal standing. Demographics, economic wealth and family prestige of course differ from one family to another. 
Citation : Fliche, Benoit (2005) 'The hemşehrilik and the village: the stakes of an association of former villagers in Ankara', European Journal of Turkish Studies, Thematic Issue $\mathrm{N}^{\circ} 2$, Hometown Organisations in Turkey, URL: http://www.ejts.org/document385.html

To quote a passage, use paragraph (§).

\section{Patrimonialisation in Ankara: hemşehrilik and the manipulation of meanings}

[23] The village clearly seems to be a restraint to associative mobilisation. The impossibility of: organising picnics in Kayalar, rebuilding the cemetery, building a tekke and planting a forest through the association indicates that the main barrier to the associative mobilisation is paradoxically the village itself. But does this mean that mobilisations occurring outside that geographical area are more likely to succeed?

[24] The initiators of the movement in fact attempted to encourage associative mobilisation through the patrimonialisation ${ }^{9}$ of historic village culture, as well as through the revival and invention of customs. These 'patrimonialising' collective actions thus have as their 'subject' communal property, which is the historic village culture. This is manifested in three main variations of traditions: the semah, the cem and the aşure çorbası.

[25] From that point on the question is whether the Kayalarlı will adhere or not to these collective actions, which must not only fit the egalitarian ideal of hemşehrilik, but also fulfil semiotic requirements by manipulating the substance of the traditions in an acceptable way for the associations' members. After illustrating the importance of this second condition through the failure of two collective actions (the semah and the cem), we will then demonstrate in a final example (the aşure çorbası) that both conditions have to be fulfilled for a successful action.

\section{The semah}

[26] The initiators of the movement largely inspired by activities organised by their counterparts throughout the country in hemşehri and Alevist associations, tried to organise village soirées (köy gecesi) based around a show: ritual dances (semah) performed by young members of the association. Yet these initiatives did not generate a following among members in the long term. Two evenings were organised around these ritual dances, but this practice did not continue afterwards: 'The first time, we held this in the marriage room in Yenimahalle. We had invited people

9 The difference between 'folklorization' and 'patrimonialisation' is subtle. Both phenomena are part of a mythification process in the sense that it covers obvious forms of 'motivation' (Barthes 1957: 199), but the specificity of folklore is that it takes the form of a visual projection. 'Folklorization' is above all a public spectacle: its first goal is to provide a 'spectacle', whereas the goal of 'patrimonialisation' is to engrain something as 'heritage', and to transform it into something which can be 'inherited'. 
Citation : Fliche, Benoit (2005) 'The hemşehrilik and the village: the stakes of an association of former villagers in Ankara', European Journal of Turkish Studies, Thematic Issue $\mathrm{N}^{\circ} 2$, Hometown Organisations in Turkey, URL: http://www.ejts.org/document385.html

To quote a passage, use paragraph (§).

from other villages, politicians of Yenimahalle, the CHP, of course ${ }^{10} \ldots$ We did it again, but it was not so good. No one came. And then, little by little, the semah group split up. We did not want to reform a group. People don't have the time'. Kayalarlı misconstrued the invitation of official people as an attempt by some leading members of the association to manipulate it in order to promote their own political careers. Here we once again meet the concern about equality and the preservation of communal property as described earlier; the Kayalarlı morally condemn using the association as a springboard for achieving personal aspirations. However, this is not the only explanation for the failure of this collective action. In fact, the semah group could have continued to exist and perform in a more politically neutral environment, or one not tainted by what, in the eyes of the Kayalarl, is judged as shocking personal conduct. But this was not the case: the group quickly split up.

[27] A supplementary explanation can be found in the manipulation of the main meaning behind the semah. Outside the fact that the techniques of the ritual dances of Kayalar had not been passed to the urban generations and that they had to be retaught with the help of a teacher of folklore, the religious sense of the semah undergoes an important alteration by being turned into a spectacle. Older people who used to dance during religious ceremonies in the village did not recognise the dances as semah. 'Galip taught us the semah. He is a schoolteacher. He used to go now and then to the Pir Sultan Abdal association and it is there where he learned them. It was his idea to form a group, as the older generation can no longer dance. My mother, she knew a little. For her, our dancing is not really the semah, but it has been forgotten,' one of the young dancers tells us.

[28] This manipulation led to important differences in how the Kayalarlı interpreted and received the ceremony. Detached from the religious ceremony of the ayin-i cem (Alevi ceremony that involved the whole village, infra), these dances were for many folkloristic - for the better but also for the worse. Generally speaking, this secular folklorization was accepted neither by the büyükler nor by the younger generation, as demonstrates this adolescent: 'It is not normal to dance the semah during marriages, for example. It is ridiculous. The semah is a prayer (ibadet), a greeting (selam). It means nothing to dance it like that. Some dance the semah in bars. It is normally impossible to do it with alcohol present. But now, they do it anyway. Normally one has to have carried out ritual washings before dancing.' When asked, the dancers defend this folklorization. Danced during these organised

10 This group of Alevi mainly supports the Cumhuriyet Halk Partisi (CHP- Kemalist) political party. 
Citation : Fliche, Benoit (2005) 'The hemşehrilik and the village: the stakes of an association of former villagers in Ankara', European Journal of Turkish Studies, Thematic Issue $\mathrm{N}^{\circ} 2$, Hometown Organisations in Turkey, URL: http://www.ejts.org/document385.html

To quote a passage, use paragraph (§).

evenings, the semah is not folklore, but keeps all its religious meaning: a 'greeting' (selam) and a 'prayer' as a young dancer explains to us: 'Folklore is one thing. The semah, it is an ibadet (cult), it is towards God. You know - well, it was like folklore (he emphasises 'like'), but it was not folklore... it is true that it was a demonstration, a spectacle, but there is also a religious meaning.'

[29] The failure of this 'patrimonial' mobilisation is thus explained by the disrespect of the hemşehrilik ideal and by the absence of a consensus on the interpretation of the semah, which due to a manipulation of its meaning, which has not been fully accepted.

\section{The cem}

[30] The example of the cem is interesting because unlike the case of the semah, those behind the project were not accused of using the association for private means. The hemşehrilik ideal was thus respected, but in spite of this, the mobilisation failed. This allows us to isolate the importance of the 'semiotic' factor in the success or the failure of this patrimonial mobilisation.

[31] One of the first initiatives of the movement was in 1998 to bring the tradition of the cem back to life, and in this way to regroup all former villagers around a religious and cultural event, which Alevist associations all over the country had also recreated. The idea was well chosen: the cem as a religious ritual seemed perfect to inject new life into the village network and give new strength to the sense of common belonging.

[32] Before the rural exodus, the ayin-i cem (ceremonies of union) took place during the winter: a dede (religious authority) and his aşı (bard) came to lead the ceremonies. The dede took the role of judge and the main purpose of the ritual of the cem was to be a people's court. Many informants in fact remember this unique legal character. To them, it was a particular moment in which one could - thanks to an independent religious authority with knowledge of the history of the village, bring problems into the public arena without resorting to official legal proceedings, which were seen as too distant. Each sülâle (patrilineage) held its own ceremony, which the entire village had to attend. Failure to attend resulted in serious trouble, and implied that the ceremony could not take place, since one of the essential conditions, which allowed it to be held, was a 'union of souls': this prayer could not take place without peace and understanding between all villagers. Thus, the cem above all meant holding up a sülâle to be judged before all the other sülâle. 
Citation : Fliche, Benoit (2005) 'The hemşehrilik and the village: the stakes of an association of former villagers in Ankara', European Journal of Turkish Studies, Thematic Issue $\mathrm{N}^{\circ} 2$, Hometown Organisations in Turkey, URL: http://www.ejts.org/document385.html

To quote a passage, use paragraph (§).

[33] The accounts of this ceremony are ambiguous. On the one hand, the informants often present this 'tribunal' as a moment where all the villagers were equal before the justice of the dede. However on the other hand, they also remember that in practice this was not the case, as people could buy a part of the defendant's wrongdoing: a fine was set, but a friend or a member of the family requested that the dede lowered it a little for him. In general, a whole network of contacts clubbed together and in this way succeeded in lowering the fine. Inequality of justice was therefore manifest (Gokalp 1980: 204-205).

[34] With urbanisation, the ceremony of the cem disappeared. One explanation is that the legal system for settling conflicts functioned badly in Kayalar. For example, it proved to be completely useless when the village was divided over the exploitation of a mine in the village at the end of the 1950s. In addition, the legitimacy of the dede underwent a crisis during the 1960s and 1970s as a growing number of villagers refused to recognise his authority. According to certain sources, the opening of the land and the politicisation in the 1970s led the villagers to take issue against the dedelik, likened to a 'feudal' 11 system. This theory seems very convincing, even more so as this is not the only village to experience a rejection of this religious authority: the same can be said of other villages of the region, even other provinces, for example Sivas.

[35] After 1975, no cem was held: urbanisation, rural to urban migration, the breakdown of the dedelik system and left-wing politicisation had deprived this religious ceremony of all meaning. Perceived as useless, even as archaic and restrictive, it was forgotten. Twenty years later it has made a comeback, but now exists in a oxymoronic manner. In its new form, the people's court no longer exists, which might lead us to believe that the cem has lost its religiosity and that when it is organised, it is on more commemorative - even folkloric lines. However, according to the organisers, this is not the case and the cem still lives on as a prayer even if the people's court is missing. 'In 1997, we organised a real cem. It was not a show. It was a real cem, but without semah. Back then we had no dancers. But it was a real ibadet (cult). We had invited some dede for it.'

[36] The dede invited to lead the ceremony are not the ones linked to the village, but came from Alevist associations: as a consequence they do not know the families of talip (disciples) among whom they will hold the ceremony. It is not by accident that the choice is made to invite 'foreign'

${ }^{11}$ Karpat mentions similar phenomena in other villages (1976: 129). 
Citation : Fliche, Benoit (2005) 'The hemşehrilik and the village: the stakes of an association of former villagers in Ankara', European Journal of Turkish Studies, Thematic Issue $\mathrm{N}^{\circ} 2$, Hometown Organisations in Turkey, URL: http://www.ejts.org/document385.html

To quote a passage, use paragraph (§).

dede: in fact, with little effort, it would be easy to find the correct dede. But inviting the dede traditionally attached to Kayalar was not desirable: for them, re-establishing contact with this ocak ('household') would result in the reestablishment of their prerogatives, which, twenty years before, had been de-legitimised. The decision to choose dede from outside the village allows the villagers to maintain more freedom towards them. That said, these foreign dede could, just like their predecessors, take on the role of the traditional judge, except that they hardly know the talip, their relationships and conflicts. In any case people would not allow this to happen, as it would be seen as an attempt to restore their power, and therefore as a return to the past - to 'feudalism', meaning an era where the dede 'were on the villagers' backs'. Consequently there is a double neutralisation of the dede: by choosing wise religious men who have never previously been in contact with the village, and by preventing them from fulfilling their legal function, the cem's function as a people's court is over-shadowed.

[37] The sidestepping taken to arrive at a new meaning of cem is not accepted by the Kayalarlı because it results in a profound change in the cem's religious connotations. It deprives the ceremony of all meaning, as much as this 'patrimonialisation' does not 'appeal' to those interested. The new ritual without a people's court is the subject of vocal criticism: 'Why organise a cem where the problems between families are not resolved? It makes no sense!' Thus, after one of the ceremonies, an old woman went to see the dede to complain about her neighbour, but the latter told her that it was none of his business and that he could do nothing for her. Her story is often used as an example to show the pointlessness of the rebirth of the ritual. So, the members of the association are clearly not convinced by the new manipulated meaning at the hands of the organisers. They do not want the absence of a people's court to 'replace' the meaning behind the ritual with a 'patrimonial' sense. They do not see any use in holding the cem ceremonies again if they do not carry out their main function of resolving conflicts between the families and individuals who participate. To many, these new ceremonies are not gerçek (real). Thus one can speak of a failure of the 'patrimonialisation', and after a second unsuccessful attempt, no organisers proposed another cem. 
Citation : Fliche, Benoit (2005) 'The hemşehrilik and the village: the stakes of an association of former villagers in Ankara', European Journal of Turkish Studies, Thematic Issue $\mathrm{N}^{\circ} 2$, Hometown Organisations in Turkey, URL: http://www.ejts.org/document385.html

To quote a passage, use paragraph (§).

\section{The aşure çorbası}

[38] The first two initiatives might lead one to think that it is difficult, and that the former villagers are resistant to mobilisation. However the 'patrimonialisation' of the aşure çorbası (the aşure soup) shows that this is not always the case. This last example of patrimonial mobilisation is more effective than the two others, mainly because it fits the hemşehrilik ideal and because it results in an alteration in meaning which is smaller and more acceptable.

[39] The aşure çorbası is a sweet soup, which is prepared at the end of fasting in the month of Muharrem to commemorate the martyr Hüseyin in Kerbala (680). It is made up of twelve ingredients, the number referring to the twelve imams but also to the twelve days of fasting. Before mobilisation, the aşure was prepared and eaten in the family, after which it was offered to visiting guests, parents, friends and neighbours. The aşure therefore did not take the form of a collective ritual. It was both prepared and remained resolutely in the private sphere: it circulated, yes, but only within networks of alliances in the large sense, meaning friends and the extended family. Nonetheless under the direction of leaders of the association, this soup acquired new meaning and shape. It is now cooked and distributed collectively to the members of the association, while at the same time conserving its sacred character. Over a period of a few weeks, the president of the association collects money to purchase the necessary ingredients. The day before aşure, the older women meet and begin preparing the ingredients. Early in the morning, they start the cooking process which lasts several hours. The group meal is served at around midday: everyone is given a bowl of hot soup. Generally, it is also an opportunity to approve the association's budget. The men assemble and chat while the treasurer tries to find out who has not paid his contribution. Unlike the two previous attempts, this soup is a moment of successful village mobilisation.

[40] First of all one will notice that compared with other 'patrimonilisations', this one does not make any great modification to the pre-existing meaning. This clearly gives a clue why the cem and the semah did not work well: mobilised people tend to reject great changes in meaning. Collective enthusiasm only appears for cultural forms that change sparingly in their semiotic sense. The more the meaning is distorted, the less the collective action is effective. In addition, the collective use of the association, principally by the older women, did not give rise to suspicions of 'privatising' or using the association for a personal benefit. 
Citation : Fliche, Benoit (2005) 'The hemşehrilik and the village: the stakes of an association of former villagers in Ankara', European Journal of Turkish Studies, Thematic Issue $\mathrm{N}^{\circ} 2$, Hometown Organisations in Turkey, URL: http://www.ejts.org/document385.html

To quote a passage, use paragraph (§).

[41] The success of the former annual associative picnic before various conflicts between villagers appeared, demonstrates a similar logic: it was not about the reinstatement of a village tradition but an innovation by the initiators of the movement. Elements of the village's past are not present and thus not manipulated. In addition, the association acting as a whole, especially the major role again played by elder women, eliminates suspicion that the association is being used to promote private interests, and so the hemşehrilik ideal is respected. In fact, during the association's first years of existence, the picnic was without a doubt the kind of mobilisation that worked best.

\section{Conclusion}

[42] What should be remembered from this monographic approach of an association from Ankara? First of all, we can see that the Kayalarlı do not adhere to all the reinstatements and inventions of traditions. Not only do they have to be acceptable on a semiotic level, they also have to fit the hemşehrilik ideal, meaning the concern for equality between members of the group and for use of communal property. This leads us to the conclusion that the association of Kayalar is not a village association but an association of hemşehri.

[43] In addition to the generation gap, we have seen that one of the main obstacles to associative mobilisation was, paradoxically, the village itself. This observation invites us to dissociate two elements that tend to be united: the village and the association - even if the village is the reason why the association is created. By doing this, we disestablish the tie that former villagers hold with their place of origin. Moreover, it seems that in order to fully understand the meaning of the term hemşehri, the researcher should not concentrate on the place of origin, but, more importantly on the underlying ideals and representations, which Turkish people emphasise when referring to each other using this word. In short, the 'hem' deserves more attention than the 'şehri'. 
Citation : Fliche, Benoit (2005) 'The hemşehrilik and the village: the stakes of an association of former villagers in Ankara',

European Journal of Turkish Studies, Thematic Issue $\mathrm{N}^{\circ} 2$, Hometown Organisations in Turkey, URL: http://www.ejts.org/document385.html

To quote a passage, use paragraph (§).

\section{References}

Barthes, Roland (1970) Mythologies, Paris, Seuil.

Bayraktar, Serdar (2001) Associations de pays : les fers de lance du clientélisme politique urbain, Mémoire de fin d'études, Istanbul, Université de Galatasaray.

Bozarslan, Hamit (1999) 'Le phénomène milicien : une composante de la violence politique dans la Turquie des années 1970', Turcica XXXI, pp. 185-244.

Cuisenier, Jean (1975) Economie et Parenté. Leurs affinités de structure dans le domaine turc et dans le domaine arabe, Paris, Mouton.

Elias, Norbert (1986) 'Notes sur le commérage', Archives de la Recherche en Sciences Sociales 60, pp. 23-29.

Erder, Sema (1996) Istanbul'a bir kent kondu : Ümraniye, Istanbul, lletişim.

Fliche, Benoit (2004) ' 'La modernité est en bas' : ruralité, urbanité chez les habitants d'un gecekondu d'Ankara', European Journal of Turkish Studies, Thematic Issue n¹, Gecekondu, URL : http://www.ejts.org/document67.html

Fliche, Benoit (2005) 'De l'action réticulaire à la recherche du semblable, ou comment faire lien avec l'administration en Turquie', in Dorronsoro, Gilles (dir.), La Turquie conteste. Mobilisations sociales et régime sécuritaire, Paris, Editions du CNRS.

Gokalp, Altan (1980) Têtes Rouges et Bouches Noires. Une confrérie tribale de l'ouest anatolien, Paris, Société d'ethnographie.

Güneş Ayata, Ayşe (1990) 'Gecekondular Kimlik Sorunu, Dayanışma Örüntüleri ve Hemşehrilik' Toplum ve Bilim 51/52, pp. 89-101.

Hobsbawm, Eric ; Ranger Terence (1983) The invention of Tradition, Cambridge, Cambridge University Press.

Karpat, Kemal (1976) The Gecekondu - Rural Migration and Urbanization, Cambridge, Cambridge University Press.

Lenclud, Gérard (1987) 'La tradition n'est plus ce qu'elle était... Sur les notions de tradition et de société traditionnelle en ethnologie', Terrain 9, pp. 110-123.

Massicard, Elise (2001) 'Sivas, une province de Turquie entre local et global', Etudes du CERI 79, Paris, Sciences-Po, URL : http://www.ceri-sciences-po.org/publica/etude/etude79.pdf

Massicard, Elise (2002) Construction identitaire, mobilisation et territorialité politique. Le mouvement aléviste en Turquie et en Allemagne depuis la fin des années 1980, Thèse de doctorat en science politique, Institut d'Etudes Politiques de Paris.

Pérouse, Jean-François (2005) 'Phénomène migratoire, formation et différenciation des associations de hemşehri à Istanbul : chronologies et géographies croisées' European Journal of Turkish Studies, Thematic Issue $n^{\circ} 2$, Hometown Organisations in Turkey, URL : http://www.ejts.org/document369.html 
Citation : Fliche, Benoit (2005) 'The hemşehrilik and the village: the stakes of an association of former villagers in Ankara', European Journal of Turkish Studies, Thematic Issue $\mathrm{N}^{\circ} 2$, Hometown Organisations in Turkey, URL: http://www.ejts.org/document385.html

To quote a passage, use paragraph (§).

Shankland, David (2003) The Alevis in Turkey: the emergence of secular Islamic tradition, London, Routledge Curzon.

Siméant, Joanna (1998) La cause des sans-papiers, Paris, Presses de Sciences Po. 